\title{
COMPATIBILITY BETWEEN THE SPURR FUNCTION VOLUME AND THE KOZAK'S TAPER FUNCTION AND QUINTIC POLYNOMIAL VOLUMES FOR BLACK WATTLE TREES
}

\author{
Marcos Behling $^{1 *}$, Henrique Soares Koehler ${ }^{2}$, Alexandre Behling ${ }^{3}$ \\ ${ }^{1 *}$ Federal University of Paraná, Department of Forest Resources, Curitiba, Paraná, Brazil - mcosbehling@ gmail.com \\ ${ }^{2}$ Federal University of Paraná, Graduation Program, Curitiba, Paraná, Brazil - koehler@ufpr.br \\ ${ }^{3}$ Federal University of Paraná, Graduation Program, Curitiba, Paraná, Brazil - alexandre.behling@ yahoo.com.br
}

Received for publication: 19/12/2019 - Accepted for publication: 09/03/2020

\begin{abstract}
Resumo
Compatibilidade do Volume da Função De Spurr com a de Afilamento De Kozak e Polimônio de $5^{\circ}$ Grau para Árvores de Acácia Negra. Na modelagem do afilamento e volume, deseja-se que as estimativas do volume obtidas por meio desses dois métodos sejam compatíveis, no qual as estimativas de volume total do fuste não devem diferir quando empregadas uma equação de volume total e do volume calculado pela integração da equação de afilamento. Existem vários desses sistemas propostos na literatura, na qual modificações nos modelos de volume e afilamento foram realizadas para obtenção de sistemas compatíveis. No presente trabalho, foi proposta uma ideia para obter a compatibilidade de maneira mais simples, sem a necessidade de modificar os modelos de volume e afilamento. Assim, o objetivo geral deste estudo foi desenvolver e apresentar um procedimento para obter a compatibilidade do volume da função de spurr com a de afilamento de kozak e polimônio de $5^{\circ}$ grau para árvores da espécie Acacia mearnsii De Wild e comparar os resultados com o método tradicional desse mesmo sistema de equações. Os procedimentos propostos foram aplicados em dados da espécie Acacia mearnsii De Wild (acácia negra) nos municípios de Cristal, Piratini e Encruzilhada do Sul no estado do Rio Grande do Sul. O conjunto de dados foi composto por 343 árvores com idade variando de 5 a 10,75 anos. A qualidade do ajuste para as equações de volume e de afilamento ajustadas por meio dos procedimentos 1 e 2 é similar e ambos são compatíveis. O sistema de equações apresentado no procedimento 2 é mais simples para ser aplicado quando comparado com o procedimento 1.

Palavras-chave: sistemas de equações, compatibilidade, afilamento, volume.
\end{abstract}

\begin{abstract}
When modeling the taper and volume, it is desired that the volume estimates obtained by using these two methods are compatible, where the total stem volume estimates shall not differ when using a total volume equation and the volume calculated by integrating the taper equation. There are several of such systems proposed in the literature, in which modifications in the volume and taper models were made to obtain compatible systems. This paper introduces an idea to obtain compatibility in a simpler way, without the need to modify the volume and taper models. Thus, the overall objective of this study was to develop and present a procedure to obtain compatibility between the Spurr function volume and the Kozak's taper function and quintic polynomial volumes for Acacia mearnsii De Wild trees and compare the results to the traditional method of the same system of equations. The procedures proposed were applied on data on the Acacia mearnsii De Wild (black wattle) species in the towns of Cristal, Piratini, and Encruzilhada in the south of the state of Rio Grande do Sul, Brazil. The data set included 343 trees ranging from 5 to 10.75 years of age. The quality of the fitting for the volume and taper equations fitted using procedures 1 and 2 is similar, and both are compatible. The system of equations presented in procedure 2 is simpler to be applied when compared to procedure 1 .

Keywords: systems of equations, compatibility, taper, volume.
\end{abstract}

\section{INTRODUCTION}

There are two main methods to estimate the stem volume, namely: i) develop a model to estimate the stem volume for a fixed upper diameter; ii) develop a taper function and get estimates of the merchantable volume by parts, and in total using the integration of the taper function.

When modeling the taper and volume, it is desired that the volume estimates obtained by using these two methods are compatible, where the total stem volume estimates shall not differ when using a total volume equation and the volume calculated by integrating the taper equation.

This research context was first used by Demaerschalk (1971, 1972, 1973), Munro and Demaerschalk (1974), and Goulding e Murray (1975). Recent applications were developed by Zhao et al. (2018), Corral-Rivas et al. (2017), Lynch et al. (2017), Zheng et al. (2017), Özçelik and Crecente-Campo (2016), Nunes, Tomé and Tomé (2010), and Crecente-Campo et al. (2009). In Brazil the modeling of volume equations compatible with the taper equation has not been widely used, and the work developed by Môra et al. (2014) stands out.

Maintaining the compatibility of volume estimates, derived from the two ways of obtaining it, is a practical problem of interest to companies and researchers. Thus, the justification for this research is based on the

FLORESTA, Curitiba, PR, v. 51, n. 2, p. 521-530, abri1/jun 2021.

Behling, M. et.al.

ISSN eletrônico 1982-4688

DOI: 10.5380/rf.v51 i2. 70887 
development and presentation of a new approach to make the volume equations compatible, so as to have a simple method that results in compatible and accurate estimates of the total volume and volume by parts, therefore, useful for the practical management of forests and especially, in the volumetric results of forest inventories.

In the systems of equations used by the aforementioned researchers, the achievement of compatibility occurs by modifying the volume and taper models. In this proposal, the volume and taper models will not be modified; instead, the way to make the fitting will.

Thus, the overall objective of this study was to develop and present a procedure to obtain compatibility between the Spurr function volume and the Kozak's taper function and quintic polynomial volumes for Acacia mearnsii De Wild trees. Additionally, compare the results obtained to those using the system of equations proposed by Demaerschalk $(1971,1972,1973)$, which was defined as the research control method.

\section{MATERIALS AND METHODS}

\section{Purpose of the study}

Out of the most widely cultivated forestry species in Brazil, the Acacia gender is the fourth most planted, covering an area of 148,311 ha (ABRAF, 2013). Acacia mearnsii De Wild, known as the black wattle, is planted in several countries, especially in South Africa and Brazil (BECK et al.,1998).

In Brazil, the species was introduced in the state of Rio Grande do Sul by Alexandre Bleckmann in 1918, but its commercial use started only in 1940, driven by tannin extraction companies. The species has a great economic potential, promising in agroforestry systems, whose wood is used as raw material in the paper and pulp, plywood (ROVERSI et al., 2002), and high-quality charcoal (HUANG et al., 1994) industries, and recently, there has been increasing interest in the biomass to manufacture pellets for power generation. Tannin is removed from its bark and used in several industrial sectors such as tanneries, adhesives, petroleum products and rubbers (ABRAF, 2013). Black wattle forestry is a solid economic activity and has brought benefits and prosperity to over 40 municipalities and to approximately 40,000 families (STEIN and TONIETTO, 1997; SCHNEIDER and TONINI, 2003).

With the increasing demand for timber products in the market, and the leveraging of the Brazilian forestry sector, it is important to use measurement techniques to make a more accurate and complete diagnosis of the species' productivity. The result of using these techniques will directly influence the planning and decision-making processes for the success of the business of cultivating the black wattle as a whole; however, the procedure studied herein will allow to measure the volume of a tree or the annual increment of the forest, or yet, the total volume of commercial wood that a forest will produce during its cycle in a more accurate and quick manner.

\section{Source of the data}

The data was sampled from stands of black wattle in the state of Rio Grande do Sul, in the surroundings of the municipalities of Cristal, Encruzilhada do Sul, and Piratini (Table 1). These regions concentrate most plantations of this species.

Four circular plots with a diameter of 10 meters $\left(78.54 \mathrm{~m}^{2}\right)$ were randomly allocated at each stand. All trees in the plots were felled and the following characteristics were measured: diameter at breast height, total height and cubic volume of the stem. Thus, this study involved the allocation of 24 temporary sample plots, whose central coordinates are shown in Table 1, and 343 trees from the plots were measured.

The diameters $\left(d_{i}\right)$, taken in $\mathrm{cm}$, were measured at relative heights $\left(h_{i}\right)$ of $5 \%, 15 \%, 25 \%, 35 \%, 45 \%$, $55 \%, 65 \%, 75 \%, 85 \%$, and $95 \%$ in relation to the total height, in addition to the diameter at breast height $(d)$.

The total stem volume outside bark $\left(v_{f}\right)$ was calculated using Huber's formula. To calculate the total volume a minimum crown diameter outside bark was not taken into account.

$$
v_{f}=\sum_{i=1}^{n} \frac{\pi}{4} d_{i}^{2} l_{i}
$$

Where:

$v_{f}=$ stem total volume outside bark, in $m^{3}$.

$d_{i}=$ diameter measured at the center of the $i$ section segment, in $\mathrm{cm}$.

$l=$ section length $i$, in $\mathrm{m}$.

\section{Taper equations volume and stem volume obtained using systems of equations - Procedure 1}

Demaerschalk (1971, 1972, 1973), Munro and Demaerschalk (1974), and Goulding and Murray (1975) presented approaches to make the volumes estimated using the total volume equation compatible with those estimated using the integration of the taper equation. This was known as compatible volume and taper equations. According to those authors, to make the volumetric equations compatible for a combination of Spurr's volume

FLORESTA, Curitiba, PR, v. 51, n. 2, p. 521-530, abril/jun 2021. 
model and Kozak's taper model, the way used to ensure the compatibility is expressing the $\beta$ coefficient of Spurr's combined variable model without the independent term, based on the parameters estimated in a taper function, or vice-versa, using, for this purpose, a proportion of compatibility between two equations. The compatibility is obtained using the volume estimation system derived from Kozak's taper function, according to the following models:

Spurr: $v=\beta d^{2} h$

Kozak: $d_{i}^{2}=\left[\beta_{1}\left(\frac{h_{i}^{2}}{h^{2}}-1\right)-\beta_{2}\left(\frac{h_{i}}{h}-1\right)\right] d^{2}$

Where:

$v=$ total volume, in $\mathrm{m}^{3}$.

$d=$ diameter at breast height, in $\mathrm{cm}$.

$h=$ total height, in $\mathrm{m}$.

$d_{i}=$ stem diameter at $h_{i}$ height, in $\mathrm{cm}$.

$h_{i}=$ stem height at a given section, in $\mathrm{m}$.

$\beta=$ model parameters to be estimated.

The integration of the taper function between the base and the apex of the stem turns out to be an expression similar to Spurr's combined variable model, that is:

$$
\begin{aligned}
& v=\int_{0}^{h} \frac{\pi}{4} d_{i}^{2} d h_{i} \\
& v=\int_{0}^{h} \frac{\pi}{4}\left[\beta_{1}\left(\frac{h_{i}^{2}}{h^{2}}-1\right)-\beta_{2}\left(\frac{h_{i}}{h}-1\right)\right] d_{i}^{2} d h_{i} \\
& v=\frac{\pi}{4} d^{2} h\left(\frac{\beta_{2}}{2}-\frac{2 \beta_{1}}{3}\right) \\
& v=\beta d^{2} h, \text { where } \beta=\frac{\pi}{4}\left(\frac{\beta_{2}}{2}-\frac{2 \beta_{1}}{3}\right)
\end{aligned}
$$

Thus, the compatibility between the total volume function and the taper function is due to the $\beta$ parameter of the total volume function, and it is given by the relation with the $\beta_{i}$ parameters of the taper function, therefore:

$$
\beta=\frac{\pi}{4}\left(\frac{\beta_{2}}{2}-\frac{2 \beta_{1}}{3}\right)
$$

The compatibility between the taper function and the total volume function does not depend on the method used to estimate the parameters. However, we chose to fit both equations (total volume function and taper function) using a system of equations where the $\beta$ parameter of the total volume function has to be replaced by the function with the $\beta$ coefficients.

The fitting using a system of equations enables to obtain a minimum error sum of squares of the system comprised of the two functions (total volume and taper) as a whole, i.e., simultaneously minimize diameter errors at different heights (taper function) and volume estimate errors (total volume function).

The major problem in relation to the third approach to make the volume of the two functions compatible, regarding the simultaneous fitting, is that the number of observations used in each function is not the same. For each tree there is only one total volume observation to fit the total volume function; however, there is more than one observation per tree to express the diameters at different heights.

To develop this operation a special structure was used to accommodate the data in a table, so the observation of total volume of each tree was repeated at every diameter observation at different heights for the same tree. As in the research a collection with a fixed number of diameters along the stem was carried out, it was not necessary to use weights (reverse of the number of observations for each tree) to balance the differences in the number of diameter observations along the height of each tree, as usually happens.

In the system of equations, the parameters were estimated using seemingly unrelated regressions. This way, the system of compatible volume equations was defined as follows:

$$
\begin{aligned}
& v=d^{2} h\left[\frac{\pi}{4}\left(\frac{\beta_{2}}{2}-\frac{2 \beta_{1}}{3}\right)\right] \\
& d_{i}=\sqrt{\beta_{1}\left(\frac{h_{i}^{2}}{h^{2}}-1\right)-\beta_{2}\left(\frac{h_{i}}{h}-1\right)} d
\end{aligned}
$$

Where:

$v=$ stem volume, in $\mathrm{m}^{3}$.

FLORESTA, Curitiba, PR, v. 51, n. 2, p. 521-530, abril/jun 2021. 
$d=$ diameter at breast height, in $\mathrm{cm}$.

$d_{i}=$ stem diameter at a $h_{i}$ height, in $\mathrm{cm}$.

$h=$ stem total height, in $\mathrm{m}$.

$\beta_{1}$ and $\beta_{2}=$ model coefficients to be estimated.

The system of equations was fitted simultaneously using seemingly unrelated regressions - SUR), according to Diéguez-Aranda et al. (2006). expressions:

Thus, the system of equations consisting of $v$ and $d_{i}$ models can be presented as the following

$$
\begin{aligned}
& {\left[\begin{array}{l}
y_{1} \\
y_{2}
\end{array}\right]=\left[\begin{array}{cccc}
X_{1} & 0 & \cdots & 0 \\
0 & X_{2} & \cdots & 0
\end{array}\right]\left[\begin{array}{l}
\beta_{1} \\
\beta_{2}
\end{array}\right]+\left[\begin{array}{l}
\varepsilon_{1} \\
\varepsilon_{2}
\end{array}\right]} \\
& y=X \beta+\varepsilon
\end{aligned}
$$

Where:

$y_{1}=$ stem volume, in $\mathrm{m}^{3}$.

$y_{2}=$ stem diameter at a $h_{i}$ height, in $\mathrm{cm}$.

$X_{1}=d^{2} h$, in $\mathrm{cm}^{2} \mathrm{~m}$.

$X_{2}=d$, in cm, $\frac{h_{i}^{2}}{h^{2}}-1$ and $\frac{h_{i}}{h}-1$, dimensionless.

$\beta_{1}=$ stem total volume model coefficients.

$\beta_{2}=$ taper model coefficients.

Once the SUR model is defined, the $\beta$ solution is carried out using the generalized least squares - GLS estimator. Taking the concepts introduced by Greene (2008), for the SUR model the GLS estimator is given by:

$$
\beta=\left(X^{\prime} \Omega^{-1} X\right)^{-1} X^{\prime} \Omega^{-1} y
$$
is defined by:

The $\Omega$ matrix contains the elements of the residuals' matrix of the total volume and taper functions, as it

$$
\Omega=\sum \otimes I
$$

Where:

$\sum$ = covariance matrix of the total volume and taper functions' residuals, previously obtained by fitting these two functions in an independent manner using an ordinary least squares estimator $\left[\beta=\left(X^{\prime} X\right)^{-1} X^{\prime} y\right]$.

$\otimes=$ Kronecker's product.

$I=$ an identity matrix of $n$ (número de observações) order.

The residuals' covariance matrix $\left(\sum\right)$ was obtained from:

Where:

$$
\begin{aligned}
& \sum=\left[\begin{array}{ll}
\sigma_{11} & \sigma_{12} \\
\sigma_{21} & \sigma_{22}
\end{array}\right] \\
& \hat{\sigma}_{i j}=\frac{\varepsilon_{i}^{\prime} \varepsilon_{j}}{\left[\left(n-K_{i}\right)\left(n-K_{j}\right)\right]^{\frac{1}{2}}}
\end{aligned}
$$

$\sigma_{i j}=$ covariance between the disturbances of the total volume and taper functions for each sample observation. $K_{i}$ and $K_{j}=$ number of parameters of each $i$ and $j$ equations, in this case equivalent to 2 .

$n=$ number of observations.

In this case, the residuals' covariance values come from residuals obtained using least squares estimators. That is to say, the total volume and taper equations are estimated independently using the ordinary least squares, thus obtaining the errors associated to each equation, and then, consistently estimate the elements that comprise $\sum$.

As the $\Omega$ matrix is given by its reverse, so the $\beta$ estimator can be defined as:

$$
\beta=\left[X^{\prime}\left(\Sigma^{-1} \otimes I\right) X\right]^{-1} X^{\prime}\left(\Sigma^{-1} \otimes I\right) y
$$

Where: $\Omega^{-1}=\Sigma^{-1} \otimes I$

Proposal to make taper equations volume and stem total volume compatible - Procedure 2 The simplest way to obtain the volume of a tree is by using the form factor, that is:

$$
v_{i}=f f_{i}\left(d^{2} h\right)_{i} \frac{\pi}{4}
$$


The form factor $(f f)$ of an $i$ tree is obtained by the ratio of the stem volume $\left(v_{i}\right)$ to the volume of the cylinder, that is:

$$
f f_{i}=\frac{v_{i}}{\left(d^{2} h \frac{\pi}{4}\right)_{i}}
$$

Every tree will result in a form value and the average value of all tress $(\overline{f f})$ can be used to estimate the volume of the trees using the expression below:

$$
\hat{v}_{i}=\overline{f f}\left(d^{2} h\right)_{i} \frac{\pi}{4}
$$

When fitting the Kozak's taper model, for instance, it is assumed that the fitted coefficients represent the average tree form $(\overline{f f})$. Taking the integral of this function and obtaining the total volume $\left(\hat{v} K_{i}\right)$, so this volume is an estimator of the observed volume $\left(v_{i}\right)$, however, considering the average tree form. Then, replacing these conceptions in expression 3, we have:

$$
\hat{v} K_{i}=c\left(d^{2} h\right)_{i}
$$

The value of $c$ must be a constant and represents a combination of the average form factor with $\frac{\pi}{4}$ assumed in the coefficients in the Kozak's taper function, for instance. Thus, the total volume of a tree from the taper function can be obtained using expression 5 , which is similar to expression 3 .

$$
\hat{v}_{i}=c\left(d^{2} h\right)_{i}
$$

Therefore, the proposal to achieve compatibility between the total volume obtained using the Kozak's taper model and a total volume model is obtained following the steps below:

1 - Fit the Kozak's taper function

$$
\text { Kozak: } \frac{d_{i}}{d}=\sqrt{\beta_{0}+\beta_{1}\left(\frac{h_{i}}{h}\right)+\beta_{2}\left(\frac{h_{i}}{h}\right)^{2}}
$$

2 - Get the stem volume estimated using the integral of Kozak's function, such as:

3 - Get the $c$ constant, where:

$$
\hat{v} K_{i}=\int_{0}^{h} \frac{\pi}{4} d^{2}\left[b_{0}+b_{1}+\frac{h_{i}}{h}+b_{2}\left(\frac{h_{i}}{h}\right)^{2}\right]
$$

$$
c \frac{\pi}{4}=\frac{\hat{v} K_{i}}{\left(d^{2} h\right)_{i}}
$$

This ratio, when applied individually for each $i$ tree, shall result in the same value.

Expression 8, can be rewritten as 9, which represents a combination of the average form and the value of $\frac{\pi}{4}$.

$$
c=\frac{\hat{v} K_{i}}{\left(d^{2} h\right)_{i}}
$$

4 - The total volume estimated using the expression $\hat{v}_{i}=c\left(d^{2} h\right)_{i}$ shall result in the same value obtained in step 2, i.e., $\hat{v}_{i}=\hat{v} K_{i}$. One must notice that all the operations shall be carried out using $d$ and $h$ taken in meters.

In steps 1 and 2, Kozak's model can be replaced by other taper function, such as, for example, the traditional quintic polynomial, which was applied in this study. Next, steps 3 and 4 were kept as presented. Thus, in this proposal the modeling is made with regression in two stages. The modeler may also prefer to use the regression in three stages, so to consider the residuals' covariance (as done in Procedure 1).

\section{Assessment of the procedures}

The three procedures were assessed using the following criteria:

i) Quality of the equations' fitting

Estimates of total volume and diameters along the stem were carried out. These estimates were compared using a Chi-squared test to test the hypothesis that the values estimated using both approaches are not different, at 95\% probability. The Fitting was also assessed in terms of correlation between the values observed and estimated (r), $\bar{R}^{2}, S_{\bar{y} x}$ and also by applying a regression of the estimated values in relation to the observed values.

ii) Compatibility of the volume estimates

FLORESTA, Curitiba, PR, v. 51, n. 2, p. 521-530, abril/jun 2021 
The compatibility of the volume estimates was assessed using compatibility, where the estimates were considered compatible if the difference between the volume estimated using the volume equation and the volume estimated using the integration of the taper function was equal to zero.

\section{RESULTS}

Volume from taper equations and stem volume obtained using systems of equations - Procedure 1

The equation to estimate the volume resulted in the following coefficients and statistics:

$v=d^{2} h\left[\frac{\pi}{4}\left(\frac{1.487297}{2}-\frac{20.386575}{3}\right)\right]$

$\bar{R}^{2}=98.33 \%, S_{\bar{y} x}=8.20 \%$

The equation to estimate the diameters along the stem resulted in the following coefficients and statistics:

$$
\begin{aligned}
& d_{i}=d \sqrt{0.3886575\left(\frac{h_{i}^{2}}{h^{2}}-1\right)-1.487297\left(\frac{h_{i}}{h}-1\right)} \\
& \bar{R}^{2}=96.80 \%, S_{\bar{y} x}=9.28 \%
\end{aligned}
$$

\section{Proposal to make the volume from taper equations and the stem total volume compatible - Procedure 2}

\section{Compatibility with Kozak's function}

The equation to estimate the diameters along the stem, using Kozak's model, resulted in the following coefficients and statistics (which were recalculated for the $d_{i}$ variable).

$$
\begin{aligned}
& d_{i}=d \sqrt{1.114527-1.392878\left(\frac{h_{i}}{h}\right)+0.267001\left(\frac{h_{i}}{h}\right)^{2}} \\
& \bar{R}^{2}=96.90 \%, S_{\bar{y} x}=9.08 \%
\end{aligned}
$$

The total volume estimate using the fitted Kozak's function $\left(v K_{i}\right)$, was given by the integral of the previous function, that is:

$$
v K_{i}=\frac{\pi}{4} d^{2}\left[1.114527 h_{i}+\frac{-1.392878 h_{i}^{2}}{2 h}+\frac{0.267001 h_{i}^{3}}{3 h^{2}}\right]_{h_{1}}^{h_{2}}
$$

where $h_{1}=0$ up to $h_{2}$, in this case $h_{2}$ is equivalent to the total height.

The $c$ constant resulted in $c=0.3982662$, for all the trees (Figure 1). Therefore, the tree's total volume can be obtained using expression 12 . The intercept coefficient for equation 12 was equal to zero.

$$
\begin{gathered}
\hat{v}_{i}=0.3982662\left(d^{2} h\right)_{i} \\
\bar{R}^{2}=98.49 \%, S_{\bar{y} x}=7.79 \%
\end{gathered}
$$

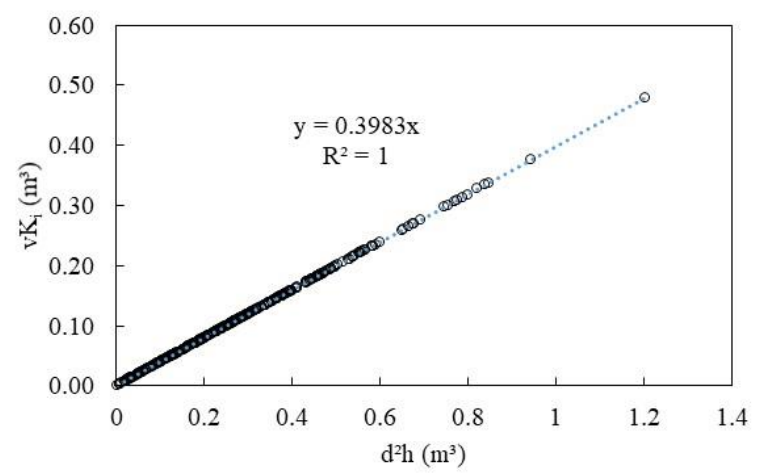

Figure 1: Compatibility constant to obtain the volume using Kozak's taper function with the Spurr volume function, for black wattle trees in the state of Rio Grande do Sul, Brazil.

Figura 1: Constante de compatibilidade para obtenção do volume por meio da função de afilamento de Kozak com a de volume de Spurr, para árvores de acácia negra no estado do Rio Grande do Sul. compatible.

The $\hat{v}_{i}=\hat{v} K_{i}$ condition was proven, i.e., the volumes obtained using expressions (11) and (12) are 
It is worth noting that the average form factor observed $(\overline{f f})$ was 0.504962 . Therefore, $c=0.3982662$ is an approximation of $\overline{f f} \frac{\pi}{4}=0.396596$.

\section{Compatibility with the Quintic Polynomial function}

The equation to estimate the diameters along the stem, using the Quintic Polynomial, resulted in the following coefficients and statistics.

$$
\begin{gathered}
\frac{d_{i}}{d}=1.12878-2.03475\left(\frac{h_{i}}{h}\right)+7.02810\left(\frac{h_{i}}{h}\right)^{2}-16.16884\left(\frac{h_{i}}{h}\right)^{3}+17.33274\left(\frac{h_{i}}{h}\right)^{4}-7.33490\left(\frac{h_{i}}{h}\right)^{5} \\
\bar{R}^{2}=96.30 \%, S_{\bar{y} x}=8.05 \%
\end{gathered}
$$

The estimate of the total volume using the fitted Quintic Polynomial function $\left(v P 5_{i}\right)$, was given by the integral of the previous function, that is:

$$
\begin{aligned}
& v P 5_{i}=\frac{\pi}{4} d^{2}\left[\frac{1}{11} \frac{b_{5}{ }^{2} h_{i}^{11}}{h^{10}}+\frac{1}{5} \frac{b_{4} b_{5}{ }^{10}}{h^{9}}+\frac{1}{9}\left(\frac{2 b_{5} b_{3}}{h^{8}}+\frac{b_{4}{ }^{2}}{h^{8}}\right) h^{9}+\frac{1}{8}\left(\frac{2 b_{3} b_{4}}{h^{7}}+\frac{2 b_{5} b_{2}}{h^{7}}\right) h^{8}+\frac{1}{7}\left(\frac{2 b_{2} b_{4}}{h^{6}}+\frac{2 b_{5} b_{1}}{h^{6}}+\right.\right. \\
& \left.\frac{b_{3}{ }^{2}}{h^{6}}\right) h^{7} \frac{1}{6}\left(\frac{2 b_{1} b_{4}}{h^{5}}+\frac{2 b_{3} b_{2}}{h^{5}}+\frac{2 b_{5} b_{0}}{h^{5}}\right) h^{6}+\frac{1}{5}\left(\frac{b_{2}{ }^{2}}{h^{4}}+\frac{2 b_{4} b_{0}}{h^{4}}+\frac{2 b_{1} b_{3}}{h^{4}}\right) h^{5}+\frac{1}{4}\left(\frac{2 b_{3} b_{0}}{h^{3}}+\frac{2 b_{1} b_{2}}{h^{3}}\right) h^{4}+\frac{1}{3}\left(\frac{b_{1}{ }^{2}}{h^{2}}+\right. \\
& \left.\left.\frac{2 b_{2} b_{0}}{h^{2}}\right) h^{3}+\frac{b_{0} b_{1} h^{2}}{h}+b_{0}{ }^{2} h\right]_{h_{1}}^{h_{2}} \\
& \text { where } h_{1}=0 \text { up to } h_{2} \text {, in this case } h_{2} \text { is equivalent to the total height. }
\end{aligned}
$$

The $c$ constant resulted in $c=0.3974451$, for all the trees (Figure 2). Therefore, the tree's total volume can be obtained using expression (13). The intercept coefficient for equation 12 was equal to zero.

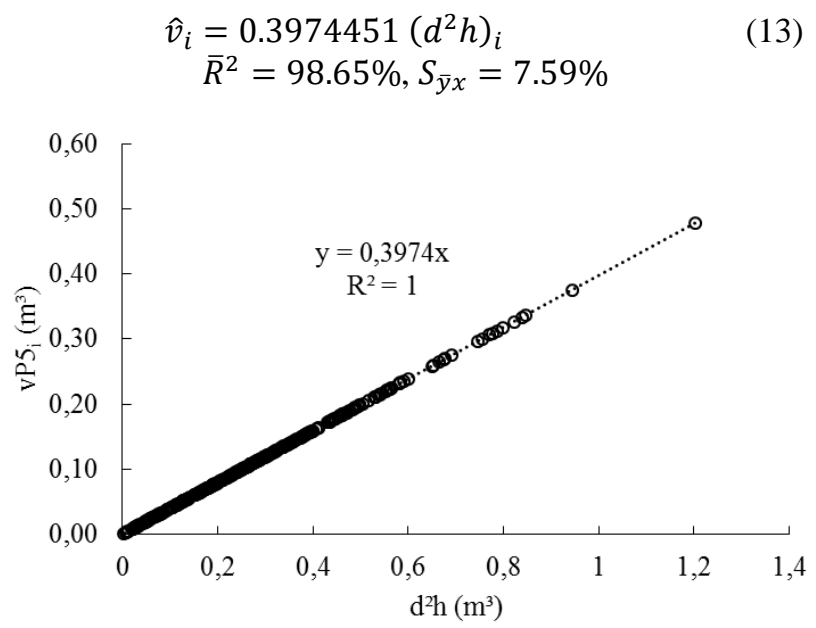

Figure 2: Compatibility constant to obtain the volume using the quintic taper function with the Spurr volume function, for black wattle trees in the state of Rio Grande do Sul, Brazil.

Figura 2: Constante de compatibilidade para obtenção do volume por meio da função de afilamento de quinto grau com a de volume de Spurr, para árvores de acácia negra no estado do Rio Grande do Sul.

The $\hat{v}_{i}=\hat{v} P 5_{i}$ condition was proven, i.e., the volumes obtained using expressions (11) and (12) are compatible.

It is worth noting that the average form factor observed $(\overline{f f})$ was 0.504962 . Therefore, $c=0.3974451$ is an approximation of $\overline{f f} \frac{\pi}{4}=0.396596$.

\section{Quality of the equations' fitting}

The value of the Chi-squared applied to assess the differences in estimates of value of diameter along the stem using Procedures 1 and 2 (using Kozak's function) was 0.1298, which is insignificant at an $\alpha=5 \%$ level, indicating that the estimates do not differ from one another. These results were also proven for the stem volume estimate, where the Chi-squared value was 0.3979. The results of diameter estimates for Procedure 2, using the quintic polynomial function to estimate both the diameters and the volume, do not differ from Procedure 1 as well, according to the application of the Chi-squared test ( 0.127 and 0.3965 , respectively). 

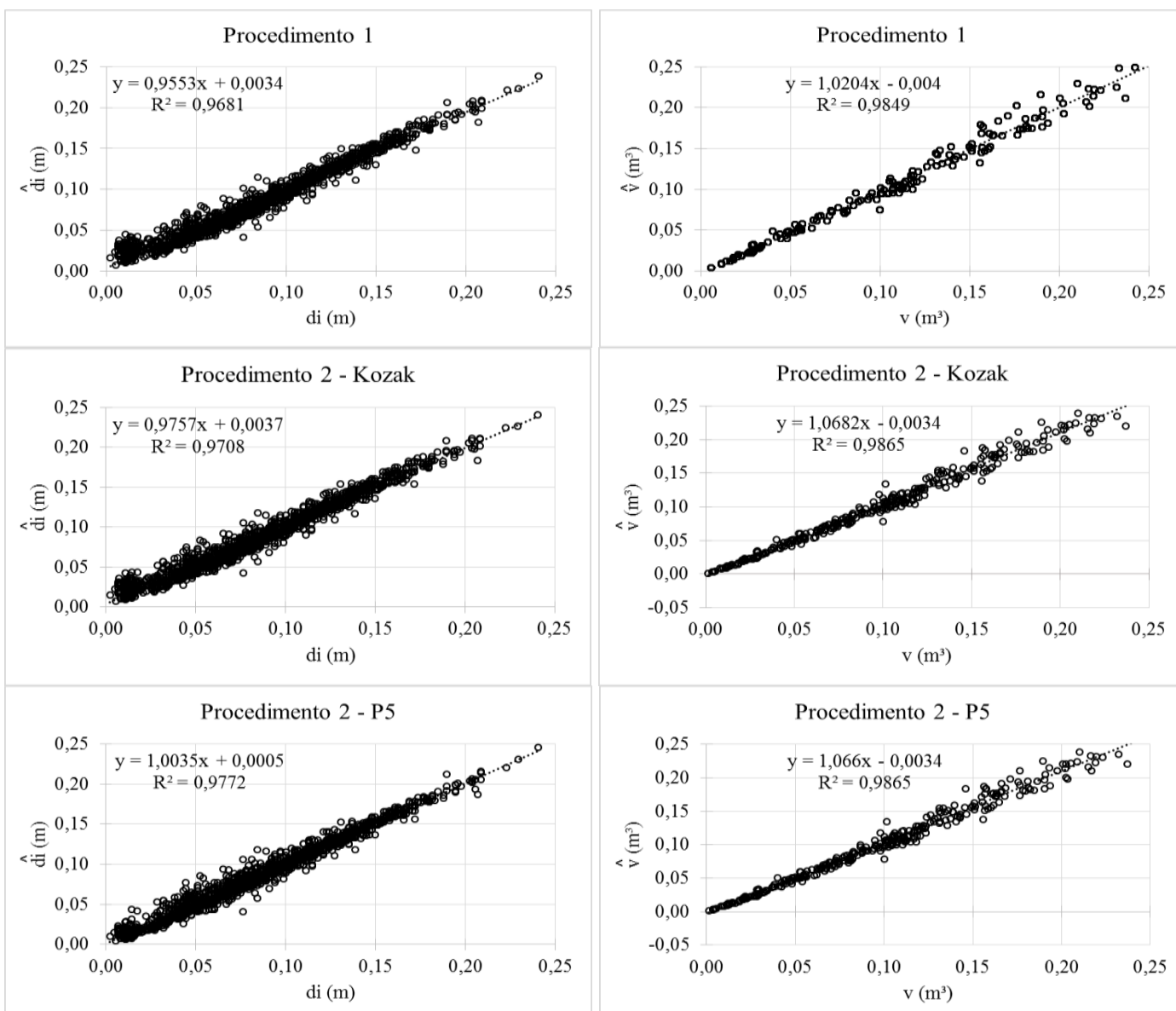

Figure 3 - Diameter values observed along the stem and stem volume, and estimated using Procedures 1 and 2, for black wattle trees in the state of Rio Grande do Sul, Brazil.

Figura 3 - Valores observados de diâmetro ao longo do fuste e volume do fuste e estimados por meio dos Procedimentos 1 e 2, de árvores acácia negra no estado do Rio Grande do Sul.

\section{DISCUSSION}

A characteristic that is sought for the modeling of volume and taper equations is to achieve compatibility, which means, that the volume estimates values do not differ from the values obtained using the integration of the taper function. Additive equations are necessary to estimate total volume (which corresponds to the total volume of components) or stem components volume, which for the black wattle can be stomp and tops volume and volume for the woodchips industry. Obviously, the application of the procedures tested in this study on other species in which the wood is classified in assortments is more interesting.

By examining the statistics used to assess the modeling, it can be noted that the application of the two procedures was adequate to estimate volumes and diameter along the stem and that both produced similar estimates. For both procedures, volume estimate compatibility was observed, which is a desirable characteristic in modeling.

In Procedure 1, the additivity of the estimates is obtained because the total volume equation consists of the same coefficients of the taper equation. To obtain it, transformations in the original model are necessary, so to force the compatibility between the estimates by using the coefficients. For this reason, it is necessary to develop a system of equations for each type of combination between the taper model and the volume model, which is not a simple task. In Procedure 1, the compatibility between the volume function and the taper function does not depend on the coefficients' estimate process, but it depends instead on the $(\beta)$ restriction functions.

Diéguez-Aranda et al. (2006) tested a series of systems of equations proposed by several researchers, each one containing the modification necessary in the models to force the achievement of compatibility. Some of these systems are complex, especially to be used in the daily routine of the Forestry Engineer at a company in a swift manner, for instance, because it demands deep and specific knowledge on the subject. On the other hand, this is not a problem for applications in research, where the modelers are more familiar with the skills required.

FLORESTA, Curitiba, PR, v. 51, n. 2, p. 521-530, abril/jun 2021. 
In Procedure 2, the additivity of the volume estimates was naturally obtained, and no modifications in the models were necessary to force compatibility. The proposed modeling is simpler when compared to Procedure 1, but the estimate accuracy is similar to that obtained in Procedure 2. Therefore, the target proposed at the introduction of this study, which required a simple method that resulted incompatible and accurate total, and by parts, volume was accomplished.

Both procedures tested are useful for the practical management of forests and, especially, for the assessment of total volumes and by assortments in forest inventories. Thus, it is believed that both procedures tested are appropriate for the modeling, and the second is simpler.

It is widely known that at Forest Engineering Academies and forestry companies the most frequently used volume models are Spurr and Schumacher-Hall models, and for taper, Kozak's and quintic polynomial models. Surprisingly, when testing Procedure 2 for any combination of these four models, following the 4 steps proposed, compatibility was also achieved (these results were no presented in this paper). This would not be easily achieved had the Procedure 1 idea been used, although the systems already exist and can be found checking out the work by Zhao et al. (2018), Corral-Rivas et al. (2017), Lynch et al. (2017), Zheng et al. (2017), Özçelik and CrecenteCampo (2016), Tang et al. (2016), Özçelik and Göçeri (2015), Môra et al. (2014), Özçelik and Brooks (2012), Nunes, Tomé and Tomé (2010), and Crecente-Campo et al. (2009), and others.

It is noted that the Schumacher-Hall model fitting was carried out in its linear mode $\left(\ln v=\ln b_{0}+\right.$ $\left.b_{1} \ln d+b_{2} \ln h\right)$. In the resulting equations, modification was obtained only in the intercept coefficient, since the form in Kozak's taper equations and quintic polynomial is a constant and does not change with the size of the tree. Moreover, it was noted a value of two for the $b_{1}$ coefficient and one for $b_{2}$, which recalls the same exponents of the simpler model to estimate a tree's volume $\left(\hat{v}=\overline{f f} d^{2} h \frac{\pi}{4}\right)$. This way, the value of the $b_{0}$ coefficient is a confounding of $\ln \left(\overline{f f} \frac{\pi}{4}\right)$, where $\overline{f f}$ is the average form modeled by Kozak's taper function or the quintic polynomial function.

The authors believe that new ideas, so to improve the volumetric estimators in forests, will be proposed by other researchers considering the idea in procedure 2 , which is the reason why this study was sent for publication in the Revista Floresta.

\section{CONCLUSIONS}

- The quality of the fitting for the volume and taper equations fitted using procedures 1 and 2 is similar and they are compatible.

- $\quad$ The system of equations presented in procedure 2 is simpler to be applied when compared to procedure 1 .

\section{ACKNOWLEDGEMENTS}

The author acknowledges TANAGRO S.A. and TANAC S.A. for their support to conduct the field research, as well as the support by the Coordination for the Improvement of Higher Education Personnel (CAPES).

\section{REFERENCES}

BECK, S. L.; DUNLOP, R.; van STADEN, J. Meristem culture of Acacia mearnsii. Plant Growth Regulation, Dordrecht, v. 32, n. 1, p.49-58, 2000.

CLUTTER, J.L. Development of taper functions from variable-top merchantable volume equations. Forest Science, v. 26, p. 117-120, 1980.

CRECENTE-CAMPO, F.; ALBORECA, A.R.; DIÉGUEZ-ARANDA, U. A merchantable volume system for Pinus sylvestris L. in the major mountain ranges of Spain. Annals of Forest Science, v. 66, p.1- 12; 2009.

CORRAL-RIVAS, J.J.; VEGA-NIEVA, D.J.; RODRÍGUEZ-SOALLEIRO, R. et al. Compatible system for predicting total and merchantable stem volume over and under bark, branch volume and whole-tree volume of pine species. Forests, v. 8, p. 1-18, 2017.

DEMAERSCHALK, J.P. Taper equations can be converted to volume equations and point sampling factors. The Forestry Chronicle, v. 47, p. 352-354, 1971.

DEMAERSCHALK, J. Converting volume equations to compatible taper equations. Forest Science, v.18, n.3, p. 241-245, 1972.

FLORESTA, Curitiba, PR, v. 51, n. 2, p. 521-530, abril/jun 2021. 
DIÉGUEZ-ARANDA, U.; CASTEDO-DORADO, F.; ÁlVAREZ-GONZÁLES, J.G.; ROJO, A. Compatible taper function for Scots pine plantations in northwestern Spain. Canadian Journal of Forest Research, V. 36, p. 1190-1205, 2006.

GOULDING, C.J.; MURRAY, J.C. Polynomial taper equations that are compatible with tree volume equations. New Zealand Journal of Forestry Science, v. 5, p. 313-322, 1975.

GREENE, W.H. Econometric analysis. Upper Saddle River: Prentice-Hall, 2008. 1178p.HUANG, F. H.; ALKHYRI, J. M.; GBUR, E. E. Micropropagation of Acacia mearnsii. In Vitro Cellular \& Developmental Biology, v.30, p. 70-74, 1994.

KRISNAWATI, H. A compatible estimation model of stem volume and taper for Acacia mangium willd. Plantations. Indonesian Journal of Forestry Research. Pulau Fordate, v. 3, n. 1, p 49 - 64, 2016.

KRISNAWATI, H. A compatible estimation model of stem volume and taper for Acacia mangium Willd. Plantations. Indonesian Journal of Forestry Research, v. 3, p. 49-64, 2016.

LYNCH, T.B.; ZHAO, D.; HARGES, W.; MCTAGUE; J.P. Deriving compatible taper functions from volume ratio equations based on upper-stem height. Canadian Journal of Forest Research, v. 47, p. 1424-1431, 2017.

MÔRA, M.; FIGUEIREDO FILHO, A.; KOHLER, S.V.; MIRANDA, R.O.V. Modelos para estimavas volumétricas de fustes de Pinus taeda L. Enciclopédia Biosfera, v. 10, n. 19, p. 1320-1332, 2014.

MUNRO, D.D.; DEMAERSCHALK, J.P. Taper-based versus volume-based compatible estimating systems. The Forestry Chronicle, v. 50, p. 197-199, 1974.

NUNES, L.; TOMÉ, J.; TOMÉ, M. A system for compatible prediction of total and merchantable volumes allowing for different definitions of tree volume. Canadian Forest Servic, v. 40, p. 747 - 760, 2010.

ÖZÇELIK, R.; GÖÇERİ, M. F. Compatible merchantable stem volume and taper equations for eucalyptus plantations in the Eastern Mediterranean Region of Turkey. Turkish Journal of Agriculture and Forestry, v. 39, p. $851-863,2015$.

RODRÍGUEZ, F.; LIZARRALDE, I.; BRAVO, F. Additivity on nonlinear stem taper functions: a case for corsican pine in northern Spain. Forest Science, v. 59, p. 464 - 471, 2013.

ROVERSI, T.; MATTEI, V.; SILVEIRA JR., P.; FALCK, G. Superação da dormência em sementes de acácia negra (Acacia mearnsii Willd.). Revista Brasileira de Agrociência, Pelotas, v. 8, n. 2, p. 161-163, 2002.

STEIN, P. P.; TONIETTO, L. Black Watle Silviculture in Brazil. In: BROWN, A.G.; KO, H.C. (Ed.). Black Wattle and its Utilisation. Barton: RIRDC, 1997. p. 78-82.

ZHAO, D.; KANE, M. New variable-top merchantable volume and weight equations derived directly from cumulative relative profiles for loblolly pine. Forest Science, v. 63, n. 3: p. 261-269, 2017.

ZHAO, D. LYNCH, T.B.; WeSTFALl, J.; COULSTON, J.; KANE, M.; ADAMS, D.E. Compatibility, Development, and estimation of taper and volume equation systems. Forest Science, v. 65, n. 1, p. 1-13, 2018. DOI: https://doi.org/10.1093/forsci/fxy036 